\title{
Reproductive biology of Poecilia sphenops Valenciennes, 1846 (Cyprinidontiformes: Poeciliidae) at the Emiliano Zapata Reservoir in Morelos, Mexico
}

\author{
José L. Gómez-Márquez, Bertha Peña-Mendoza and José L. Guzmán-Santiago
}

\begin{abstract}
Poecilia sphenops is a native species recently recorded in the Balsas basin and the Amacuzac River in Morelos (Mexico), in which it is abundant and widely distributed. This study analyzed some aspects of the reproductive biology of Poecilia sphenops from the Emiliano Zapata Reservoir, in Central Mexico. Specimens were collected using a $20 \mathrm{~m}$-long seine with a $5 \mathrm{~mm}$ mesh size, from January to December 2006. A total of 581 specimens were collected: 407 females $(70.0 \%), 83$ males (14.3\%) and 91 individuals with no differentiated sex (15.7\%). Fish ranged from 20 to $96 \mathrm{~mm}$ in total length and 0.01 to $13.07 \mathrm{~g}$ in body weight. The female to male sex ratio (4.9:1) deviated significantly from the unity $\left(\chi^{2}=214.2, \mathrm{p}<0.05\right)$. Monthly variations in gonadosomatic (GSI) and hepatosomatic (HSI) indexes and ovarian development stages showed that $P$. sphenops spawning season occurred between July and October, concurring with the rainy season. Another reproduction peak was registered in February. The largest length registered for males and females was $96 \mathrm{~mm}$ and $83 \mathrm{~mm}$, respectively.

Poecilia sphenops es una especie nativa registrada recientemente en la cuenca del Balsas y el río Amacuzac en Morelos (México), en el cual es abundante y ampliamente distribuida. En este estudio se analizaron algunos aspectos de la biología reproductiva de Poecilia sphenops de la presa Emiliano Zapata, ubicada en el centro de México. Los especímenes fueron recolectados de Enero a diciembre de 2006, utilizando una red de $20 \mathrm{~m}$ de largo con una luz de malla de $5 \mathrm{~mm}$. Se recolectaron un total de 581 especímenes: 407 hembras (70.0\%), 83 machos (14.3\%) y 91 individuos indiferenciados (15.7\%). El tamaño de los peces osciló de 2 a $96 \mathrm{~mm}$ de longitud total y de 0.01 a $13.07 \mathrm{~g}$ de peso corporal. La proporción sexual de las hembras con respecto a los machos (4.9:1) se desvió significativamente de la unidad $\left(\chi^{2}=214.2, p<0.05\right)$. La variación mensual de los índices gonadosomático, hepatosomático y del desarrollo de los estadios de los ovarios, mostraron que la época de desove de $P$. sphenops se llevó a cabo entre julio y octubre, durante la época de lluvias. Otro pico de reproducción fue registrado en Febrero. La talla más grande registrada para los machos y para las hembras fue de $96 \mathrm{~mm}$ y $83 \mathrm{~mm}$, respectivamente.
\end{abstract}

Keywords: Fecundity, Poeciliids, Sex ratio, Sexual maturity, Spawning.

\section{Introduction}

Members of the Cyprinodontiformes order are cosmopolitan in tropical and temperate latitudes. Poeciliids encompass nearly 200 species of small fishes, most of them measuring less than $50 \mathrm{~mm}$ long and distributed in tropical and subtropical latitudes of the New World (Rosen \& Bailey, 1963; Meffe \& Snelson, Jr., 1989; Huidobro Campos, 2000).

Poecilia, belonging to Poeciliini, compriseds 43 species widely distributed throughout the southeastern United States, Mexico, Central America, the West Indies, and South America (north, north-central and south regions), limited by Río de la Plata in northern Argentina (Rosen \& Bailey, 1963; Parenti \& Rauchenberger, 1989; Miller et al., 2005; Nelson, 2006). The porthole viviparous Poecilia sphenops Valenciennes, 1846 in Cuvier and Valenciennes, 1846 (Rauchenberger, 1989) is distributed throughout Central America, Mexico and Colombia (Welcomme, 1988). This species is a member of the viviparous teleost poeciliids, and can be found in the Pacific slope from the middle Río Verde basin (Juchatengo, Oaxaca) in Mexico, and further east and south into Guatemala (at least reaching Escuintla), but this species is not observed in El Salvador. On the Atlantic slope it has been observed in the region

Laboratorio de Limnología, F.E.S. Zaragoza, U.N.A.M. Batalla 5 de Mayo esq. Fuerte de Loreto, Col. Ejército de Oriente, C.P. 09230 Iztapalapa, Ciudad de México. (JLG-M) lgomez@unam.mx (corresponding author), (BP-M) berthapegna@yahoo.com.mx, (JLG-S) joluguzsan@yahoo.com.mx 
between the Río de la Palma Sola, $67 \mathrm{Km}$ southsoutheast of Nautla (Veracruz), and the south of the Río Coatzacoalcos basin. This is also the case in the upper Río Grijalva basin in Mexico (Miller, 1966; Miller et al., 2005). Carrillo Wilson (1996), Contreras-MacBeath et al. (2006) and Contreras-MacBeath et al. (2014), referred to $P$. sphenops as a native species recently recorded in the Balsas basin and the River Amacuzac in Morelos (Mexico), in which it is abundant and widely distributed.

One of the most colorful and popular specimens in aquariums, the molly has been marketed in many countries around the world through the aquarium fish trade. It is surprising that this species has not been recorded in several other countries. Considering the identity confusion between this species and $P$. mexicana, it is possible that many of the introductions attributed to the latter were actually $P$. sphenops.

Ecologically, Poecilia sphenops is a very tolerant species as it inhabits slight or moderate water streams, flood water ponds, lagoons, micro-reservoirs, lakes and reservoirs, and water ranging from clear to turbid, or even muddy (Meffe \& Snelson, Jr. 1989; Miller et al., 2005). In Mexico, its commercial value is very low and there are few investigations from the ecological point of view of the impact that non-native freshwater fish have on fauna and habitats in different reservoirs.

Little data is available regarding their ecology or general biology. In spite of this, Martínez Trujilo (1983) and Trujillo-Jiménez \& Toledo Beto (2007) have conducted feeding ecology studies in Mexico. Studies on malformations in Poecilia sphenops embryos have been carried out as well (Paredes \& Mejía, 2005).

However, there are unpublished accounts of the biology of these species from the Emiliano Zapata Reservoir in Mexico. The objective of this study was to evaluate the relationship between the $P$. sphenops reproductive cycle (fecundity-length, mean length at sexual maturation, sex ratio, maturity development stages, and reproductive season) and the environmental conditions at Emiliano Zapata Reservoir, a Mexican ecosystem with eutrophic conditions.

\section{Material and Methods}

Emiliano Zapata (18³0' N; 99 $16^{\prime} 34^{\prime \prime} \mathrm{W}$ ) is a tropical man-made reservoir. It is located at an altitude of $899 \mathrm{~m}$ and belongs to the Puente de Ixtla Municipality, in the state of Morelos in Mexico (Instituto Nacional de Estadística, Geografia e Informática, 1998). The reservoir was primarily constructed to supply domestic water to Tilzapotla residents (Morelos). It also supplies water for agricultural activities within the area and for general municipal uses. Subsistence fishing activities are carried out in the reservoir. The main physical features of the reservoir are (Fig. 1): a surface area of $13.23 \mathrm{ha}$, a total capacity of $c a .1 .56$ million $\mathrm{m}^{3}$, average and maximum depths of $3.83 \mathrm{~m}$ and $17 \mathrm{~m}$, respectively. Fish samples were collected approximately in monthly periods from January to December 2006. They were caught using a $20 \mathrm{~m}$-long seine with $5 \mathrm{~mm}$ mesh size, and they were subsequently fixed with $10 \%$ formaldehyde. For the weight-length relationship, sex ratio and condition factor analyses, the allowed maximum number of specimens captured in one month was used. They were then transported to the laboratory where they were measured to the nearest $0.1 \mathrm{~cm}$ and weighed to the nearest $0.01 \mathrm{~g}$. Maturation stages in females were identified through gonadal inspection using the same technique mentioned by Mendoza (1962) and based on the Contreras-MacBeath \& Ramírez Espinoza (1996) description. The ovaries of each female caught for the study were removed and weighed. Eggs and embryos were counted and measured.

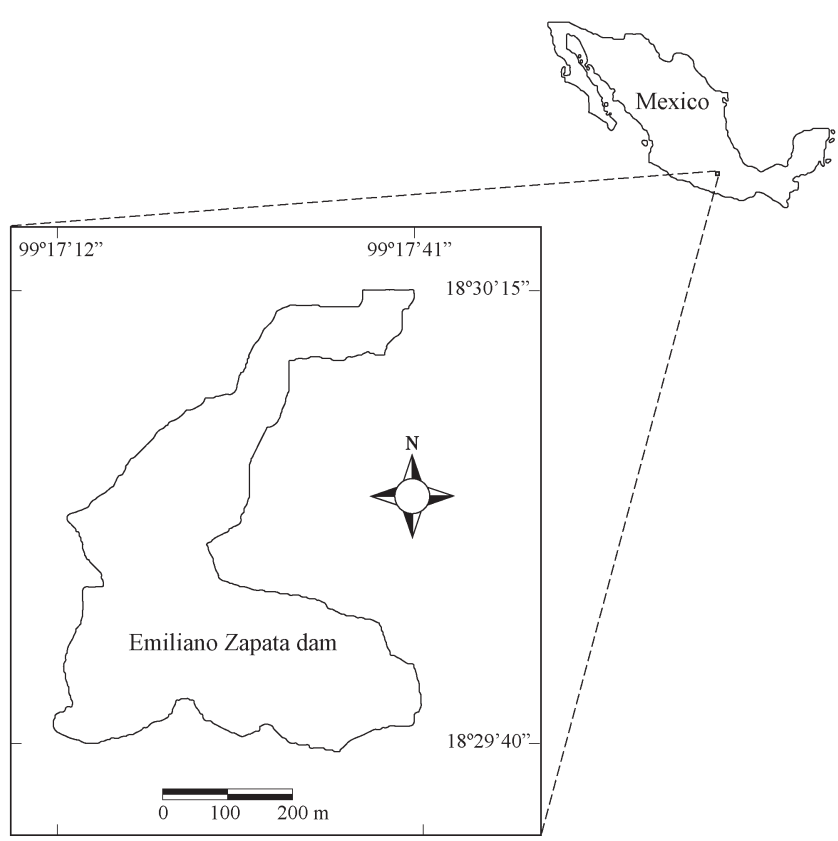

Fig. 1. Map showing location of the study area in Mexico where Poecilia sphenops samples were collected.

The gonadosomatic and hepatosomatic indexes (GSI and HSI respectively) were calculated using the following equations:

$$
G S I=\frac{W_{g}}{W_{e}} 100 \quad H S I=\frac{W_{h}}{W_{e}} 100
$$

$W_{g}$ is gonad wet weight $(g), W_{h}$ is liver wet weight and $W_{e}$ is eviscerated wet weight $(g)$. Monthly frequency of gonad stages and average monthly GSI and HSI were plotted in order to assess the fish's reproductive cycle and breeding season. To determine whether GSI values differed significantly between sexes at a $\mathrm{p}<0.05$ level, a Mann-Whitney U-test was performed. This can be considered a measurement of the reproductive cost. 
To establish size during first maturation in females, the ovaries were examined considering the criteria employed by Reznick \& Miles (1989). Size at first maturity was considered as the attained length when $50 \%$ of Stage $\mathrm{IV}$ and $\mathrm{V}$ females, from the cumulative relative female frequency at these stages, were fitted to the logistic model proposed by Sparre \& Venema (1997), according to the following equation:

$$
P=\frac{1}{1+\mathrm{e}^{(\mathrm{a}-\mathrm{bSL})}}
$$

$P$ is the proportion of mature fish defined by the interval length, whereas $a$ and $b$ are the model parameters. Once fitted, the size at first maturity (the length at which $50 \%$ of the fish are reproducing, $\operatorname{Lm~50\% )~was~calculated~as~}$ follows: $L m 50 \%=a / b$. For males, the smallest sample with completely formed gonopodial structures was considered for this calculation.

The total length (TL)-standard length (SL) relationship was calculated through the linear regression between these variables of the population. The total length (TL)total weight (TW) relationship was calculated through a power regression between these variables for each sex using the following relationship:

$$
\mathrm{TW}=a \mathrm{TL}^{b}
$$

TW is the body weight, TL is the total length, $b$ is the growth exponent or length-weight factor, and $a$ is a constant. The values of $a$ and $b$ were estimated using a "linearized" form of the previous expression by applying (base 10) logarithms on both sides of the equation, and estimating $\log a$ and $\log b$ values through a linear regression analysis using the ordinary least-square method. The student's $t$-test was applied in order to accept (or reject) the isometric growth hypothesis (Pauly, 1984). A covariance analysis allowed the identification of significant differences between both sexes regarding their length-weight relationship at $p<0.05$.

To determine physical condition over time, we calculated the monthly condition factor $(\mathrm{K})$ for both males and females using the Fulton equation (Bagenal, 1978):

$$
K=\frac{T W}{T L^{b}} * 10^{5}
$$

$T W$ is total weight $(\mathrm{g}), T L$ is total length $(\mathrm{mm})$ and $b$ is regression coefficient. The Kruskal-Wallis test $(\mathrm{p}<0.05)$ showed whether significant differences between males and females existed regarding both overall and monthly variables.

Mature females (maturity stages III, IV and V) were used to estimate fecundity, using the total number of eggs contained in one ovary (Bagenal, 1978). Fecundity variation was estimated using linear regression, taking into account brood size and total length, using logarithms for every month of the reproductive period (Bagenal, 1978). Egg and embryo sizes were measured using a Vernier caliper and the average was calculated for each specimen. Eggs and embryos from every female caught were counted. Fertility variation was estimated using linear regression, taking into account total length of both eggs and embryos (Cabrera Peña \& Solano López, 1995).

Sex ratio was analyzed for the whole population monthly. The statistical significance of the monthly ratio results was established by a fit to the Chi-squared test $\left(\chi^{2}\right)$, using a $\mathrm{p}<0.05$ value.

We tested data normality (Kolmogorov-Smirnov, $\mathrm{p}>0.10$ ) and equal variance (Levene, $\mathrm{p}<0.05$ ) assumptions, and nonparametric analyses were carried out, as the variables did not meet the premises for parametric analyses.

Some environmental factors were also investigated in order to determine if they were associated with the fish breeding cycle. Surface water temperature was measured using a thermometer, at $11: 00 \mathrm{~h}$ at each sampling event. Maximum depth was measured using a dead weight. Dissolved oxygen was monitored in situ with a Hanna portable water oximeter (model HI9146). Photosynthetic pigment (chlorophyll a) was measured spectrophotometrically using a Thermo Scientific Spectronic 20 (Wetzel \& Likens, 2000). Voucher specimens were deposited in the fish collection of Instituto de Biología, Universidad Nacional Autónoma de México (CNPE-IBUNAM14005).

\section{Results}

The total $P$. sphenops sample consisted of 581 individuals. Total body length (Fig. 2) ranged from 23 to $84 \mathrm{~mm}$ for males and from 20 to $96 \mathrm{~mm}$ for females, with a weight between 0.01 and $8.01 \mathrm{~g}$ for males and 0.04 to $13.7 \mathrm{~g}$ for females. The TL mean for females and males did not differ significantly $(t$-student $=-1.17 ; p=0.2436)$. However, the relationship between standard length and total length was statistically significant:

$$
\mathrm{SL}=-0.229+0.794 \mathrm{TL},\left(\mathrm{r}^{2}=0.9462, \mathrm{p}<0.05\right)
$$

Sexual dimorphism was evident when examining $P$. sphenops morphological features, the main sexual character being a modification of the anal fin forming a gonopodium in males.

Of the 581 specimens dissected $83(14.3 \%)$ were males, $407(70.0 \%)$ were females and $91(15.7 \%)$ were individuals with no differentiated sex. Sex ratio was 4.9:1 (female to male), which was significantly different from a 1:1 ratio $\left(\chi^{2}=214.2, p<0.05\right)$. The females dominated significantly throughout the year. The largest number of females was registered from December to March, whereas males were abundant only in July (Fig. 3). 


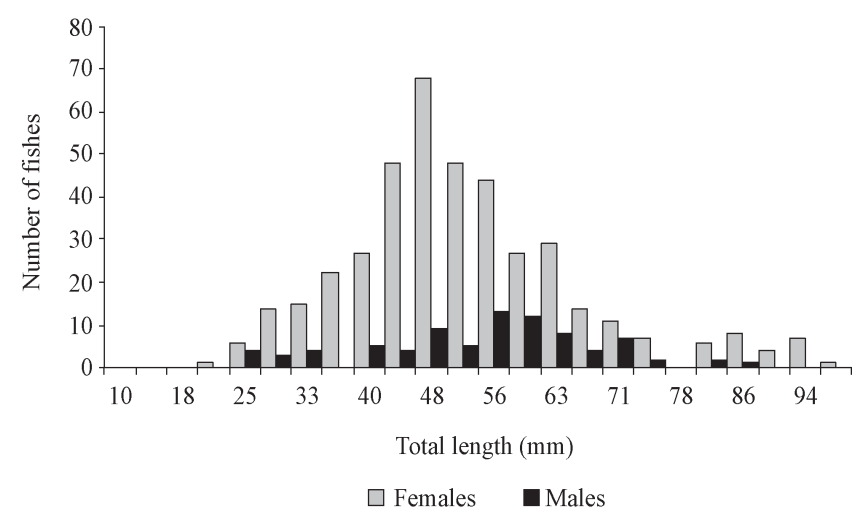

Fig. 2. Length frequency distribution by sex for Poecilia sphenops at Emiliano Zapata Reservoir, Mexico.

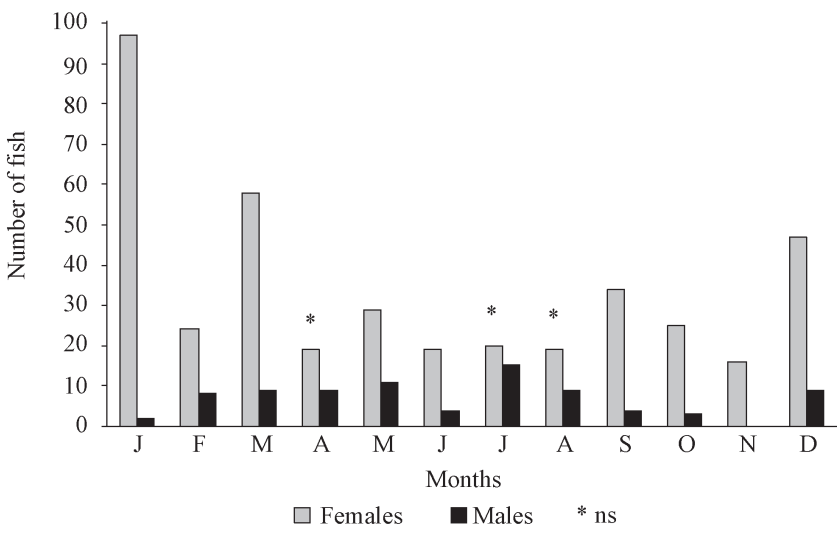

Fig. 3. Monthly sex ratio for Poecilia sphenops in the Emiliano Zapata Reservoir. Asterisks indicate not significant differences.

Due to a significant difference between slopes regarding male and female TW-TL regressions (ANCOVA; $\mathrm{F}=4.99$; $\mathrm{p}=0.0259$ ), the length-weight relationship was calculated separately for all individuals and for each sex (Fig 4). These equations are as follows:

Females: $\mathrm{TW}=0.0002 \mathrm{TL}^{2.967}, \mathrm{r}^{2}=0.9219$ Males: TW $=0.00002 \mathrm{TL}^{2.9983}, \mathrm{r}^{2}=0.9771$ All fish: TW $=0.00002 \mathrm{TL}^{2.955}, \mathrm{r}^{2}=0.9629$

Slopes of females and males, shown using the former power model, $(b=2.96$ and 2.99 , respectively) were not statistically different enough from the hypothetical value of 3 (Student's $t$-test $=1.33, p>0.05$ for females; Student's $t$-test $=0.785, p>0.05$ for males) to detect isometric growth. Their length was similar, but females were heavier (Student's $t$-test $=12.72, \mathrm{p}<0.05$ ) than males (Fig. 4).

Percentage of each gonadal development stage is represented in Fig. 5. Monthly occurrences in P. sphenops ovarian maturation stages were used to establish the breeding period of the species. According to the females' gonadal maturation stages, 21.2 percent of the total fishes were characterized as undergoing first reproduction (II), 17.5 percent were maturing (III), 8.4 percent were already mature (IV), 8.4 percent were ripe (V), and 6.5 percent were spent (VI). Therefore, 23.3 percent of all specimens were in the process of reproducing. In males, all gonads analyzed were mature the entire time.

A breeding activity was found, interpreted by the presence of development stages IV and V, which were observed during the rainy season. The highest proportion of the average gonadal ripe stage $(\mathrm{V})$ in females was exhibited from July to October (Fig. 5). However, in February another reproduction peak was registered. In contrast, specimens in spent stage (VI) were observed from April to October.
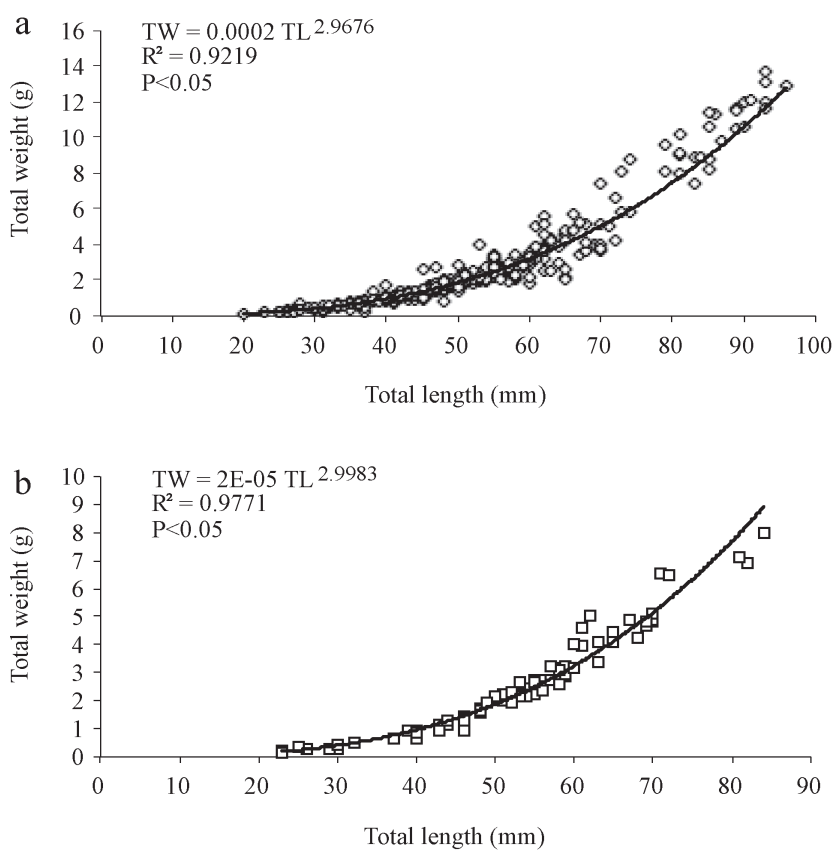

Fig. 4. Length-weight relationship for females (a) and males (b) of Poecilia sphenops.

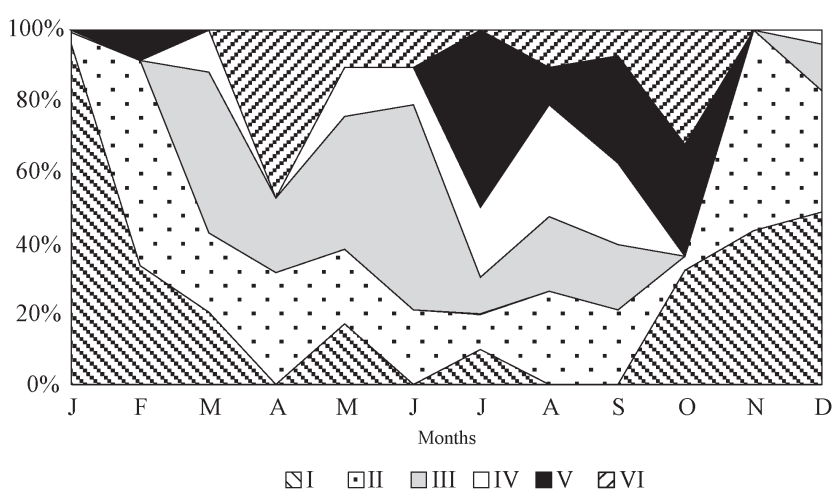

Fig. 5. Seasonal variation of development maturity ovary stages for Poecilia sphenops.

Gonadosomatic index increases with the progressive development of the gonads, in both males and females, until gonads are ripe. From that point, the index sharply declines in the spawning and spent stages. Female gonad weight could be almost $7 \%$ of the total body weight, whereas male 
gonad weight rarely reached $1.4 \%$ (Fig. 6). The increase in weight from immature to ripe condition through intermediate stages of maturation is illustrated in Fig. 6 ( $a$ and $b$ ). Regarding reproduction, the maximum value of gonadosomatic index for females was measured from July to October (Fig. 6a). In males, GSI varied very little over the year, although it was possible to determine an upward trend during August and October, when the maximum GSI was reached (Fig. 6b). However, in February and March another reproduction peak was registered. Female GSI significantly differed from month to month (Kruskal-Wallis, $\mathrm{H}=114.80$, $\mathrm{p}<0.05$ ), whereas male GSI varied throughout the year and significant differences from month to month were found (Kruskal-Wallis, $\mathrm{H}=19.97$, $\mathrm{p}<0.05$ ).
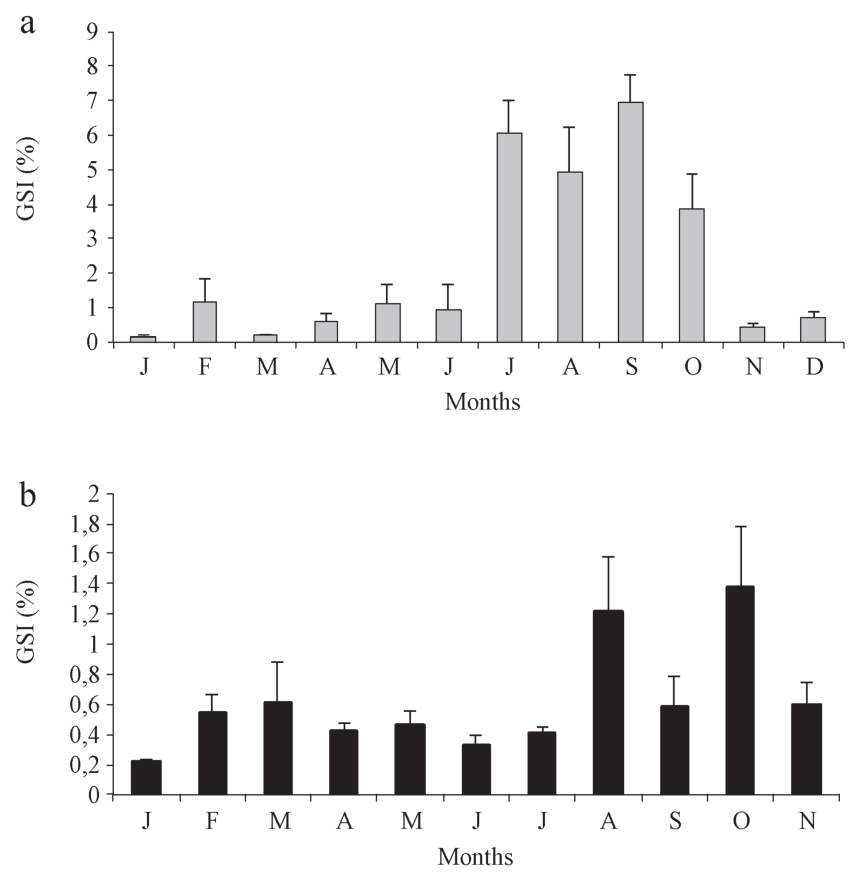

Fig. 6. Seasonal variation of the gonadosomatic index (GSI) for Poecilia sphenops females (a) and males (b).

A similar pattern between average gonad and liver weight was detected in females. Average values of the hepatosomatic index (HIS) varied significantly from month to month (Kruskal-Wallis $\mathrm{H}=88.96$; $\mathrm{p}<0.05$ ), and the maximum value of HIS for females was recorded in November (2.70), before the spawning season.

Regarding condition, not significant differences were observed between sexes (Mann-Whitney, $\mathrm{W}=44.0$, $\mathrm{p}>0.05$ ). Females were always in better condition than males (Fig. 7), and showed a similar pattern. Condition values of both males and females were similar, as calculated using total or eviscerated weight. Condition increased from January to September, especially in females, possibly due to prevailing adverse environmental conditions. When the reproductive cycle began in July, female condition improved and that of the males decreased, although it should be considered that the energy cost of embryo formation is higher than the energy cost for males. In September, maximum condition values for females were achieved as a consequence of weight increase due to embryo growth, appropriate environmental conditions (rainy season) and food availability.

The relationship between body length and gonadal development was examined in 144 specimens from randomly selected samples. Both males and females attain maturity in the first year of their life. TL of the smallest mature female was $25 \mathrm{~mm}$ whereas that of male was 40 $\mathrm{mm}$. Using logistic curve fitted values, the estimated average length at sexual maturity $(\mathrm{Lm})$ was a TL of 35 $\mathrm{mm}$ in females.

Batch fecundity (number of oocytes + number of embryos) was estimated from 144 females and ranged from 11 to 142, with an average value of 56 . There was a correlation between fecundity and body length $(\mathrm{F}=0.075$ $\left.\mathrm{TL}^{1.621} ; \mathrm{r}=0.751, \mathrm{p}<0.05\right)$. Egg diameters were $1.96 \pm 0.16$ $\mathrm{mm}$. Brood size was variable as well, ranging from 4 to 70 , with an average of 34 . We constructed several regressions and the best correlation values were between fertility and body length $(r=0.748 ; p<0.05)$, compared to those found between fertility and weight $(\mathrm{r}=0.708 ; \mathrm{p}<0.05)$, indicating that the number of embryos is influenced by the females' size. Total average length of embryos from all collected females in the aquatic system was $10.9 \pm 0.85 \mathrm{~mm}$.

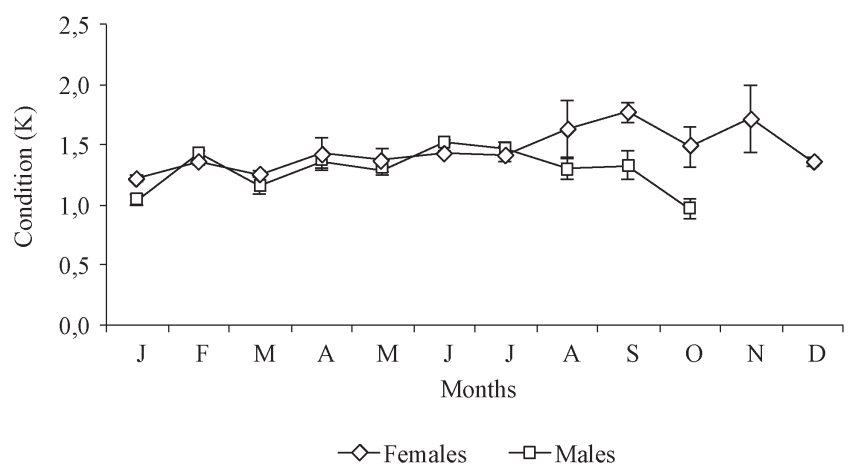

Fig. 7. Seasonal variation of the condition index (K) of $P$. sphenops in the Emiliano Zapata Reservoir.

During this study, the water level in the reservoir increased following the "heavy rain season" from June to October. The reservoir area is characterized by a dry season (November to May) and a rainy season (June to October). The maximum and minimum depths (19.5 and $6.5 \mathrm{~m}$, respectively) of the Emiliano Zapata Reservoir were recorded during the period of this study. Water temperature ranged from $21.6^{\circ} \mathrm{C}$ to $29.5^{\circ} \mathrm{C}$ during the period of this study and was relatively high from June to August. Low temperatures were recorded from December to February. Dissolved oxygen concentration ranged between 3.97 and $11.03 \mathrm{mg} / \mathrm{L}$. Regarding chlorophyll " $a$,", the data showed that phytoplankton biomass peaked during August and October (Fig. 8), during the rainy season, and decreased in the dry season (November to May). 


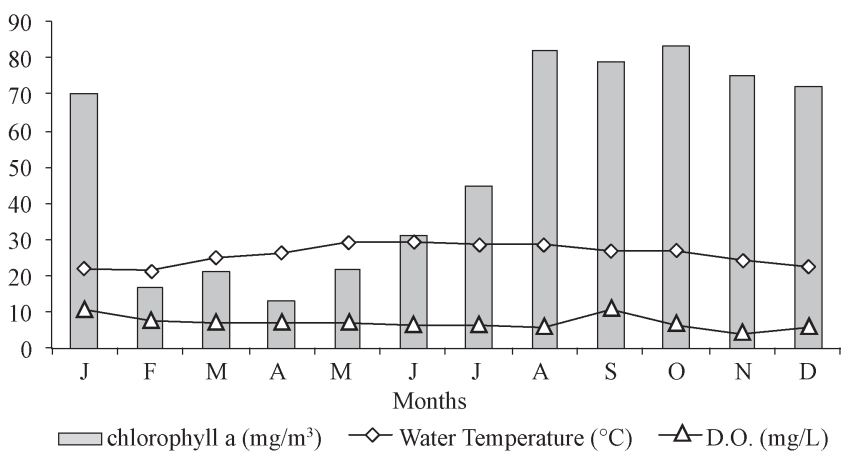

Fig. 8. Seasonal variation of chlorophyll a concentration $\left(\mathrm{mg} / \mathrm{m}^{3}\right)$, water temperature $\left({ }^{\circ} \mathrm{C}\right)$ and dissolved oxygen $(\mathrm{mg} / \mathrm{L})$ at Emiliano Zapata Reservoir.

\section{Discussion}

From December to March (cold and dry season) the largest number of Poecilia sphenops was captured in the reservoir, whereas from June to October (rainy season) the lowest number was registered. This may be influenced by the system's flood period, beginning in rainy season; by the size of the net used; and because fish were more dispersed in the reservoir during rainy season.

Poecilia sphenops is a dimorphic species with distinct sex-specific growth rates. The porthole viviparous females have longer life spans, reach larger sizes than males, can feed on a wide array of prey, and can successfully avoid predation. Together, these factors decrease their mortality rate. Similar results are consistent with those described by Ponce de León et al. (2013) for other species of the family. Males stop growing, or grow very little after their gonopodium has been completely formed, and they do not live long after reaching maturity (Snelson Jr., 1984; Snelson Jr., 1989). Reznick (1983) and Vargas \& Sostoa (1996) reported that high growth rates favor the survival of young fishes because, if they are bigger, they feed on a wider range of prey and successfully avoid predation, thus their mortality rate is decreased.

Regarding maximum size recorded for both females and males, Martínez Trujillo (1983) reported similar values for $P$. sphenops at the Zicuirán Reservoir (Michoacán), whereas Trujillo \& Toledo Beto (2007) observed similar results at Los Carros dam (Morelos). Both reservoirs are located in Mexico. Nikolsky (1978) mentioned that the larger sizes of the females result from a differential growth rate regarding males. Moreover, Ponce de León et al. (2013) reported that within the Poeciliidae family, females generally reach larger sizes in comparison to males, before being able to reproduce. This is very important in order to ensure the successful development of offspring within the ovary.

In the Emiliano Zapata Reservoir, the sex ratio is significantly biased (4.9:1), favoring females. This is in accordance with previous observations made on other poeciliids species such as Poecilia sphenops (1:5.2)
(Martínez Trujillo, 1983), P. gracilis (1:2.3) (GómezMárquez et al., 2008), P. gracilis (1:4.5) (ContrerasMacBeath \& Ramírez Espinoza, 1996), P. baenschi, (1:11) (Zuñiga-Vega et al., 2012), P. catemaconis (Lorán-Núñez et al., 2013) and in Gambusia holbrooki (1:4). Furthermore, this is a well known feature occurring in sexually dimorphic fishes, particularly within the Poeciliid family (Vargas \& Sostoa, 1996). Urriola Hernández et al. (2004a) suggests that the Poecilia reticula sex ratio was significantly male biased (1:0.49).

Snelson, Jr. (1989) mentioned that female predominance may be attributed to differential mortality based on sex. Females have higher survival rates due to their larger size, longer lifespan, less conspicuous colors, and more resistance to the rigors of reproductive effort and unfavorable environmental conditions. Rosenthal et al. (2001) reported that bright colors seem to be detrimental to the poeciliids species' survival and involves a higher risk of predation for males. In addition, males suffer higher mortality, attributable to a variety of causes including predation, greater susceptibility to stress, and accelerated physiological aging.

Devlin \& Nagahama (2002), Van Aerle et al. (2004), and Guerrero-Estévez \& Moreno-Mendoza (2010) indicated the existence of a wide variety of sexual determination mechanisms, which can influence sex proportion within a population. Studies have shown that phenotypic sex in fish can be also altered by environmental factors such as temperature (Conover \& Kynard, 1981), pH (Beamish, 1993; Römer \& Beisenherz, 1996), and a wide range of hormone-mimicking chemicals discharged into the environment (Van Aerle et al. 2004). Conover \& Heins (1987) and Karayücel et al. (2006) mentioned that female proportion of $P$. reticulata gradually increased with lower temperatures and the male proportion gradually increased with higher temperatures, rather than having a threshold response in heat-treated fry.

A length-weight relationship analysis of both male and female $P$. sphenops indicated that the species has an isometric growth, because the slope value $(b)$ did not statistically differ from its theoretical value $(b=3)$, and because of differences in the relative growth rate between the sexes. Thus, their bodies grow in the same proportion in regard to weight and length. In this study similar results (isometric growth) were observed for $P$. sphenops (Martínez Trujillo, 1983) and P. catemaconis (LoranNúñez et al., 2013). In contrast, different results (allometric growth) have been reported for other species, by ContrerasMacBeath \& Ramírez Espinoza (1996), Gómez-Márquez et al. (1999, 2008) and, Urriola Hernández et al. (2004a).

These differences could be because the length-weight relationship may be influenced by sex, gonadal maturity, geographical location, and environmental condition. In addition, it is necessary to consider that undergoing the reproductive process increases body weight without necessarily reflecting suitable physical condition. Similarly, 
the relationship between length and weight provides an index frequently used by fisheries biologists to quantify the well-being of a fish (Wootton, 1991). Accurate values for the relationship between length and weight are important, because estimates of biomass made with analytical models require individual average weight (Frota et al., 2004), which is easily obtained if the $a$ and $b$ values of this relationship are available.

Another aspect that could also have an impact on fish survival is their size at first reproduction, as the porthole viviparous reach sexual maturity at a small size within its first year and is therefore able to begin reproduction in July. The size of $P$. sphenops at maturation is not exceptional. Different sizes at first maturation have been reported for several species, by Martínez Trujillo (1983), GómezMárquez et al. (1999, 2008), Lorán-Nuñez et al. (2013) and Ponce de León et al. (2013). Additionally, Ponce de León et al. (2013) reported that females from low-lying wetlands reached smaller sizes and matured earlier in comparison with those from species groups normally inhabiting mountain streams.

This difference arises because sexual maturity is a function of size and it may be influenced by food abundance and seasonal availability, temperature, age, day length and other environmental factors at different localities (Nikolsky, 1978; Uria et al., 1998).

Monthly trend displayed by GSI variation suggests that within the population analyzed in this study gonadal growth begins in May and continues in July/ October, at which time most of the individuals within the population are spawning. In addition, seasonal trends of GSI average values can be used as a good indicator of population spawning season. After comparing the values of gonadosomatic index, hepatosomatic index and gonadal development, it is evident that the reproduction peak occurs from July to October, during rainy season. Contreras-MacBeath \& Ramírez Espinoza (1996) reported similar information for P. gracilis in Morelos (Mexico) but in a different location.

Rosen \& Bailey (1963) noted that in temperate and subtropical zones the reproductive cycles of poeciliid fishes declined in late summer and autumn and ceased altogether in winter. Cycle interruption is attributed to seasonal photoperiod fluctuations rather than temperature (Haynes \& Cashner, 1995).

Relationship between fecundity and body size showed a significant correlation. Reznick \& Miles (1989) mentioned that in non-superfetating poeciliids there is an association between body size and fecundity as in Poecilia reticulata (Thibault \& Schultz 1978), P. turrubarensis (Cabrera Peña \& Solano López, 1995), Heterandria bimaculata (Gómez-Márquez et al., 1999), and P. reticulata (Urriola Hernández et al., 2004b). Ponce de León \& Rodríguez (2010) mentioned that Cuban poeciliids exhibit a high degree of association between female total length and fecundity. Burns (1985) showed that a significant positive correlation between standard length and fecundity was observed in female $P$. sphenops in the longer photoperiod, but not for those in the shorter photoperiod. Sudha (2012) reported similar results for $P$. sphenops.

Regarding the maximum condition value that occurred in September, this coincides with rainy season when the reproductive period was highest. This condition decreased in December when water temperature decreased. Vargas $\&$ de Sostoa (1996) reported similar information for $P$. gracilis and Gambusia holbrooki, respectively. Moreover, it is possible that the combination of both lower condition and greater reproductive effort resulted in reduced individuals, as is observed during this period. Furthermore, the decreased condition has been ascribed to a depletion of body reserves during gonad maturation.

A correlation between GSI and seasonal changes in rainfall and air temperature indicates that spawning occurs mainly during the warm and rainy season. Moreover, the period with high GSI values was also that of increased phytoplankton biomass (chlorophyll a), a consequence of high nutrient levels due to water mixing and changes associated with rainfall in the reservoir's hydrology. The results presented in this study suggest a positive relationship between these abiotic variables and reproduction.

Hernández et al. (2002) have considered that $P$. sphenops is not commercially important in Mexico. Only some areas of the state of Oaxaca have artesian fisheries for human consumption and they recommend the use of this species in aquaculture, owing to its thermal plasticity (Hernández-Rodríguez \& Buckle-Ramirez, 2010; Brito et al., 2013).

The possible establishment of $P$. sphenops in the Emiliano Zapata Reservoir is of concern, because in the sites where this poeciliid is established, they tend to naturally disperse and colonize new areas. According to the reproductive information now available for this and other species of commercial importance in the reservoir, authorities need to implement a management plan that protects the population, avoid the introduction of nonnative species, assess ecological and genetic risks, and ensure a better use of aquatic resources. The support of local communities and society in general is needed because the introduction of non-native species is considered the second greatest cause of biological diversity loss, right after habitat destruction (Contreras-MacBeath et al., 2014).

The reservoir seems to be productive and will support a diversity of fishes. The $P$. sphenops population was strongly influenced by the physico-chemical factors which reflected the good water quality, according to Wetzel \& Likens (2000). Temperature, and food abundance and quality were some of the factors that could limit fish reproduction in the reservoir. The reproductive information obtained in this study of $P$. sphenops will enable fisheries to be regulated. To this date there are no specific measures implemented to regulate this resource. The size at first maturity should be considered in the exploitation. 


\section{Acknowledgements}

We sincerely thank to Facultad de Estudios Superiores Zaragoza (FES-Z), UNAM for their cooperation during this study. We thank everyone who kindly assisted in several parts of the work for collecting, processing and providing measurements of $P$. sphenops and environmental variables. Two anonymous reviewers for discussion and comments on previous versions of this manuscript. This work was supported by the Facultad de Estudios Superiores Zaragoza and the PAPIIT-DGAPA program (project code IN201105-3) and PAPIME program (project code PE205513) of National Autonomous University of México.

\section{References}

Bagenal, T. B. 1978. Aspects of fish fecundity. Pp. 75-101. In: Gerking, S. D. (Ed.). Ecology of freshwater fish production. Blackwell Scientific Publications, Oxford.

Beamish, F. W. H. 1993. Environmental sex determination in southern brook lamprey Ichthyomyzon gagei. Canadian Journal of Fisheries and Aquatic Sciences, 50: 1299-1307.

Brito, M. F. G., M. S. A. Pereira \& C. A. Figueiredo. 2013. Poecilia sphenops Valenciennes, 1846 (Cyprinodontiformes, Poeciliidae): new record in rio Sergipe basin, northeastern Brazil. Check List, 9: 1129-1131.

Burns, J. R. 1985. The effect of low-latitude photoperiods on the reproduction of female and male Poeciliopsis gracilis and Poecilia sphenops. Copeia, 1985(4): 961-965.

Cabrera Peña, J. \& Y. Solano López. 1995. Fertilidad y fecundidad en Poeciliopsis turrubarensis (Pisces: Poeciliidae). Revista de Biología Tropical, 43: 317-320.

Carrillo Wilson, C.R. 1996. Variación en la estructura de los ensambles ícticos a lo largo del río Amacuzac, Morelos. Unpublished degree Dissertation. Facultad de Ciencias Biológicas, Universidad Autónoma del Estado de Morelos, Cuernavaca, Morelos, 50p.

Conover, D. O. \& S. W. Heins. 1987. Adaptive variation in environmental and genetic sex determination in a fish. Nature, 326: 496-498.

Conover, D. O. \& B. E. Kynard. 1981. Environmental sex determination: interaction of temperature and genotype in a fish. Science, 213: 577-579.

Contreras-MacBeath, T. \& H. Ramírez Espinoza. 1996. Some aspects of the reproductive strategy of Poeciliopsis gracilis (Osteichthyes: Poeciliidae) in the Cuautla River, Morelos, Mexico. Journal of Freshwater Ecology 11: 327-338.

Contreras MacBeath, T., J. R. Bonilla Barbosa, J. C. Boyás Delgado, G. Bustos Zagal, J. M. Caspeta Mandujano, R. Castro Franco, M. A. Lozano García, J. I. Martínez Thomas, H. Mejía Mojica, A. L. Ortíz Villaseñor, D. Portugal Portugal, R. Trejo Albarrán, A. Trejo Layo \& F. Urbina Torres. 2006. Biodiversidad. Pp. 31-58. In: Contreras-MacBeath, T., F. Jaramillo Monroy \& J. C. Boyás Delgado (Coords.). La diversidad biológica en Morelos: estudio del Estado. 1a. ed. Comisión Nacional para el Conocimiento y Uso de la Biodiversidad y Universidad Autónoma del Estado de Morelos, México.
Contreras-MacBeath, T., M. T. Gaspar-Dillanes, L. HuidobroCampos \& Humberto Mejía-Mojica. 2014. Peces invasores en el centro de México. Pp. 413-424. In: Mendoza Alfaro, R. E. \& P. Koleff Osorio (Coords.). Especies acuáticas invasoras en México. México, Comisión Nacional para el Conocimiento y Uso de la Biodiversidad. http://www.biodiversidad.gob.mx/ especies/Invasoras/noticias.html.

Devlin, R. H. \& Y. Nagahama. 2002. Sex determination and sex differentiation in fish: an overview of genetic, physiological, and environmental influences. Aquaculture, 208: 191-364.

Frota, L. O., P. A. S. Costa \& A. C. Braga. 2004. Length-weight relationships of marine fishes from the central brazilian coast. NAGA, 27: 20-26.

Gómez-Márquez, J. L., J. L. Guzmán-Santiago \& A. Olvera- Soto. 1999. Reproducción y crecimiento de Heterandria bimaculata (Cyprynodontiformes: Poeciliidae) en la laguna "El Rodeo", Morelos, México. Revista de Biología Tropical, 47: 581-592.

Gómez-Márquez, J. L., B. Peña-Mendoza, I. H. Salgado-Ugarte, A. K. Sánchez-Herrera \& L. Sastré-Baez. 2008. Reproduction of the fish Poeciliopsis gracilis (Cyprinodontiformes: Poeciliidae) in Coatetelco, a tropical shallow lake in Mexico. Revista de Biología Tropical, 56: 1801-1812.

Guerrero-Estévez, S. \& N. Moreno-Mendoza. 2010. Sexual determination and differentiation in teleost fish. Reviews in Fish Biology and Fisheries, 20: 101-121.

Haynes, J. L. \& R. C. Cashner. 1995. Life history and population dynamics of the western mosquitofish : a comparison of natural and introduced populations. Journal of Fish Biology, 46: 1026-1041.

Hernández, M., L. F. Bückle \& S. Espina. 2002. Temperature preference and acclimation in Poecilia sphenops (Pisces, Poeciliidae). Aquaculture Research, 33: 933-940.

Hernández-Rodríguez, M. \& L. F. Bückle-Ramirez. 2010. Preference, tolerance and resistance responses of Poecilia sphenops Valenciennes, 1846 (Pisces: Poeciliidae) to thermal fluctuations. Latin American Journal of Aquatic Research, 38: 427-437.

Huidobro Campos, L. 2000. Filogenia del complejo Poeciliopsis gracilis Regan (Pisces: Poeciliidae) y su biogeografía. Unpublished Master in Science Dissertation, Facultad de Ciencias, U.N.A.M., México, 93p.

Instituto Nacional de Estadística, Geografía e Informática. 1998. Anuario estadístico del Estado de Morelos. Instituto Nacional de Estadística, Geografía e Informática. Aguascalientes, México, 442p.

Karayücel, I., O. Ak \& S. Karayücel. 2006. Effect of temperature on sex ratio in guppy Poecilia reticulata (Peters 1860). Aquaculture Research, 37: 139-150.

Lorán-Núñez, R. M., F. R. Martínez, A. J. Valdez-Guzmán \& E. R. Martínez-Lorán. 2013. Notas sobre la biología y la pesquería del guatopote azul Poecilia catemaconis del Lago de Catemaco, Veracruz. Ciencia Pesquera, 21: 43-46.

Martínez Trujillo, M. 1983. Contribución al conocimiento de la biología de Poecilia sphenops Valenciennes (Pisces: Poeciliidae), en la presa de Zicuirán, Mich. Unpublished degree Dissertation, Universidad Michoacana de San Nicolás de Hidalgo, Morelia, México, 64p. 
Meffe, G. K \& F. F. Snelson, Jr. 1989. An ecological overview of poeciliid fishes. Pp. 13-31. In: Meffe, G. K. \& F. F. Snelson, Jr. (Eds). Ecology and evolution of livebearing fishes (Poeciliidae). Englewood Cliffs, N. J., Prentice Hall.

Mendoza, G. 1962. The reproductive cycles of three viviparous teleosts, Alloophorus robustus, Goodea luitpoldii and Neoophorus diazi. Biological Bulletin, 123: 351-365.

Miller, R. R. 1966. Geographical distribution of Central American freshwater fishes. Copeia, 1966(4): 773-802.

Miller, R. R., W. L. Minckley \& S. M. Norris. 2005. Freshwater fishes of México. Chicago, University of Chicago Press, 490 p.

Nelson, J. S. 2006. Fishes of the world. 4th ed. New York, John Wiley \& Sons, 601p.

Nikolsky, G. V. 1978. The ecology of fishes. Translated from the Russian by L. Birkett. Neptune City, NY, T. F. H., 352p.

Paredes, L. M. E. \& H. M. Mejia. 2005. Malformación en un embrión de Poecilia sphenops (Valenciennes 1846), (Pisces: Cyprinodontiformes). Kuxulkab’X (20): 49-52.

Parenti, L. R. \& M. Rauchenberger. 1989. Systematic overview of the Poeciliines. Pp. 3-12. In: Meffe, G. K. \& F. F. Snelson, Jr. (Eds). Ecology and evolution of livebearing fishes (Poeciliidae). Englewood Cliffs, N. J., Prentice Hall.

Pauly, D. 1984. Fish population dynamics in tropical waters: a manual for use with programmable calculators. Manila, Philippines. International Center for Living Aquatic Resources Management. 325p. (ICLARM, Studies and Reviews, 8. ICLARM contribution, no. 143).

Ponce de León, J.L.\& R. Rodríguez. 2010. Ecology ofCuban species of the family Poeciliidae (Teleostei: Cyprinodontiformes). Pp. 357-374. In: Uribe, M. C. \& H. J. Grier (Eds.). Viviparous fishes II. Florida, New Life Publications.

Ponce de León, J. L., R. Rodríguez \& G. León. 2013. Lifehistory patterns of Cuban poeciliid fishes (Teleostei: Cyprinodontiformes). Zoo Biology, 32: 251-256.

Rauchenberger, M. 1989. Annotated species list of the subfamily Poeciliinae. Pp. 359-368. In: Meffe, K. G. \& F. F. Snelson, Jr. (Eds). Ecology and evolution of livebearing fishes (Poeciliidae). Englewood Cliffs, N. J., Prentice Hall.

Reznick, D. 1983. The structure of guppy life histories: the tradeoff between growth and reproduction. Ecology, 64: 862873.

Reznick, D. N. \& D. B. Miles. 1989. Review of life history patterns in poeciliid fishes. Pp. 125-148. In: Meffe, G. K. \& F. F. Snelson, Jr. (Eds.). Ecology and evolution of livebearing fishes (Poeciliidae). Englewood Cliffs, N. J., Prentice Hall.

Römer, U. \& W. Beisenherz. 1996. Environmental determination of sex in Apistogramma (Cichlidae) and two other freshwater fishes (Teleostei). Journal of Fish Biology, 48: 714-725.

Rosen, D. E. \& R. M. Bailey. 1963. The poeciliid fishes (Cyprinodontiformes), their structure, zoogeography, and systematics. Bulletin of the American Museum of Natural History, 126: 1-176.

Rosenthal, G. G., T. Y. F. Martínez, F. J. García de León \& M. J. Ryan. 2001. Shared preferences by predators and females for male ornaments in swordtails. American Naturalist, 158: 146-154.
Snelson, F. F., Jr. 1984. Seasonal maturation and growth of males in a natural population of Poecilia latipinna. Copeia, 1984(1): 252-255.

Snelson, F. F., Jr. 1989. Social and environmental control of life history traits in poeciliid fishes. Pp. 149-161. In: Meffe G. K. \& F. F. Snelson, Jr. (Eds.). Ecology and evolution of livebearing fishes (Poeciliidae). Englewood Cliffs, N. J., Prentice Hall.

Sparre, P. \& S. C. Venema. 1997. Introducción a la evaluación de recursos pesqueros tropicales. Parte I; Manual. Roma, FAO, 420 p. (FAO documento técnico de pesca, no. 306/1, Rev. 2).

Sudha, C. 2012. Study on induced breeding in ornamental fish, Poecilia sphenops. European Journal of Experimental Biology, 2: 1250-1255.

Thibault, R. E. \& R. J. Schultz. 1978. Reproductive adaptations among viviparous fishes (Cyprinodontiformes: Poeciliidae). Evolution, 32: 320-333.

Uria, G., E., M. E. Moncayo L. \& R. Garibay G. 1998. Desarrollo y madurez testicular del charal Chirostoma humboldtianum (Pisces:Atherinidae), del embalse Huapango, Edo. de México. Hidrobiológica 8: 9-18.

Urriola Hernández, M., J. Cabrera Peña \& M. Protti Quesada. 2004a. Composición, crecimiento e índice de condición de una población de Poecilia reticulata (Pisces:Poeciliidae), en un estanque en Heredia, Costa Rica. Revista de Biología Tropical, 52: 157-162.

Urriola Hernández, M., J. Cabrera Peña \& M. Protti Quesada. 2004b. Fecundidad, fertilidad e índice gonadosomático de Poecilia reticulata (Pisces: Poeciliidae) en Heredia, Costa Rica. Revista de Biología Tropical, 52: 945-950.

Trujillo-Jiménez, P. \& H. Toledo Beto. 2007. Alimentación de los peces dulceacuícolas tropicales Heterandria bimaculata y Poecilia sphenops (Cyprinidontiformes: Poeciliidae). Revista de Biología Tropical, 55: 603-615.

Van Aerle, R., T. J. Runnalls \& C. R. Tyler. 2004. Ontogeny of gonadal sex development relative to growth in fathead minnow. Journal of Fish Biology, 64: 355-369.

Vargas, M. J. \& A. de Sostoa. 1996. Life history of Gambusia holbrooki (Pisces, Poeciliidae) in the Ebro delta (NE Iberian Peninsula). Hydrobiologia, 341: 215-224.

Welcomme, R. L.. 1988. International introductions of inland aquatic species. Rome, FAO 318p., (FAO fisheries technical paper, no. 294).

Wetzel, R. G. \& G. E. Likens. 2000. Limnological analyses. 3rd. ed. New York, Springer-Verlag, 429p.

Wootton, R. J. 1991. Ecology of teleost fishes. New York, Chapman \& Hall, 404p. (Fish and fisheries series, 1).

Zúñiga-Vega, J. J., A. L. Hernández-Rosas, A. Molina-Moctezuma, H. A. Pérez-Mendoza, F. R. Rodríguez-Reyes, Y. M. BravoEspinosa \& H. Espinosa-Pérez. 2012. Population abundance and sex ratio of the viviparous freshwater fish Poeciliopsis baenschi (Poeciliidae) throughout its range in western Mexico. Western North American Naturalist, 72: 357-368.

Submitted September 01, 2014 Accepted January 20, 2016 by Clarice Fialho 